\title{
Türk Spor Basınında Cinsiyet Ayrımcılı̆̆ı: Fotomaç ve Fanatik Gazeteleri Örneği
}

\author{
MEHMET BÜYÜKAFŞAR*
}

mehmetbuyukafsar@gmail.com

Özet: Toplumsal değerler sistemi erkekliğe ayrıcalıkl bir konum sunmaktadır. Erkekler, toplumsal alanda kendilerine yüklenen ağır işler sebebiyle bu ayrıcalıklı konumu hak ettiklerini düşünürler. Ailede başlayan toplumsal cinsiyet öğrenimi, sosyal ilişkilerle devam ettirilir. Bu öğrenimi kitlelere yayan bir araç olarak medya, toplumsallaşma sürecinde önemli bir rol oynamaktadır. Toplumsal cinsiyetlerine göre kadınlı̆̆ı ve erkekliği belirleyen ayrıştırma, ayrımcılık anlamı yüklenerek, sosyal kurumlar tarafından toplumun her alanında sürdürülmektedir. Ataerkil sisteme dayalı toplum yapısı, cinsiyet temelli ayrımcılı̆̆ın ortaya çıkmasındaki başlıca sebeplerden birisidir. Ataerkil topluluklarda kadınlar her zaman geleneksel rolleriyle var olurlar. Çocukları büyütmek ve temizlik yapmak gibi sorumluluklar yüklenen kadının aksine erkek, gücün ve dayanılılığın simgesi olarak görülür ve önemli işlerle görevlendirilir. Toplumun her alanında olduğu gibi kadınlar spor alanında da ikinci plana itilmektedir. Güç, rekabet, hırs ve çatışma konularıyla özdeşleştirilen spor alanı, erkekler kadar fiziksel güce sahip olmayan kadınları yok saymaktadır. Bu nedenlerden dolayı, spordaki kadın ve erkek eşitsizliği, bu çalışmanın odaklandığı temel noktadır. Spor basınının haber söylemi aracılığıyla yayılan erkek egemenliği konusu da bu çalışmanın üzerinde durduğu diğer bir önemli konudur. Bu bağlamda Türk spor basını, çalışmanın araştırma bölümü için seçilmiştir. Türk spor basının en önde gelen iki gazetesi, Fotomaç ve Fanatik gazetelerin 2013, 2014 ve 2015 yıllarındaki birer haftasına ait sayıları incelenip, cinsiyet ayrımcıliğına yönelik bulgular araştırılmıştır.

Anahtar kelimeler: Toplumsal Cinsiyet, Cinsiyetçilik, Spor, Spor Basını, Ayrımcılık.

\section{Giriş}

İçerisinde yaşadığımız toplumun cinsiyetlere özgü olarak nitelendirdiği birçok iş ve sorumluluk vardır. Yüzyıllardır süregelen kültürün ürünü olan toplumsal değerler, toplum içerisinde varlığını sürdüren bireylerden, kadınlardan ve erkeklerden ayrı ayrı beklentilere sahiptir. Biyolojik ve fizyolojik olarak farklılıklar gösteren kadın ve

\footnotetext{
* Arş. Gör., Marmara Üniversitesi, İletişim Fakültesi, Gazetecilik Bölümü.
} 
erkek, bu farklılıklarından yola çıkılarak toplumsal olarak da birbirinden ayrıştırılmıştır. Toplumsal norm ve değerler sisteminde iki ayrı kutba oturtturulan bireyler, doğdukları andan itibaren kendilerinden beklenen rolleri ve sorumlulukları öğrenmeye başlarlar. Doğurganlıkları sebebiyle geleneksel rolleriyle özdeşleştirilen kadınlar, ataerkilliğin geçerliliğini sürdürdüğü toplumlarda, erkeklere yüklenen değerler neticesinde, ikincil konumdadır. Kendilerine yüklenen önemli iş ve sorumluluklar karşısında kadınlara göre ayrıcalıklı bir konumu hak ettiği düşünülen erkekler ise toplumda egemendir. İlk olarak aile ve sosyal çevre tarafından başlatılan kadın ve erkek arasındaki ayrıştırma, medya tarafından devam ettirilmekte ve tekrarlar sayesinde pekiştirilmektedir. Medya, toplumsal cinsiyet kalıplarının, kimliklerinin ve rollerinin bireyler tarafından benimsenmesi aşamasında önemli bir rol oynar. Aile ve sosyal çevre tarafından başlatılan toplumsal cinsiyet eğitimi, medyanın bir eğitim aracına dönüşmesiyle ve toplumsal cinsiyet mesajlarının dağıtıcısı rolüne bürünmesiyle geniş kitlelere aktarılmaktadır. Toplumsallaşma sürecindeki bu önemli işlevleri nedeniyle medya, yapılan bu çalışmanın da önemli bir yerini teşkil etmektedir. Çekişmenin ve rekabetin en üst seviyelere çıktı̆̆ı spor alanı ise erkek gücünün yüceltildiği ve kadınların önemsizleştirildiği alanların başında gelmektedir. Bu bağlamda çalışma kapsamında spor ve temsil konusuna odaklanılarak, Türk spor basının toplumsal cinsiyet kalıp yargılarından etkilendiğini, kadın ve erkek için ayrı ayrı tutumlar benimsediğini ortaya koyması bakımdan 2013, 2014 ve 2015 yıllarının rastgele seçilen birer haftasına ait Fotomaç ve Fanatik gazeteleri, en çok okuyucuya ulaşan gazeteler olması nedeniyle incelenmiştir. Türk spor basının haber diline yansıyan, kadın ve erkeği ayrıştıran toplumsal cinsiyet kalıp yargıları, söylemler aracılığyla kitlelere yayılmakta ve medyanın tekrarları sayesinde bireylere benimsetilmektedir. Elde edilen araştırma sonuçlarıyla, yazılı basın tarafından beslenen toplumsal cinsiyet eşitsizliklerinin farkına varılma noktasında bir katkı sağlanması amaçlanmıştır.

\section{Toplumsal Cinsiyet Kavramı ve Kapsamı}

Cinsiyet kavramını, biyolojik bir terim olarak ortaya koyan Ann Oakley, toplumsal cinsiyet kavramını ise psikolojik ve kültürel bir terim olarak ifade eder. Cinsiyet, kadın ve erkek arasındaki biyolojik farklılı̆̆ın ötesinde, kültürden kültüre değişen, anlam kazanan bir kavramdır. Antropologlar, cinsiyet kavramını, birbirlerinden farklı olarak tanımlayan birçok kültür ve toplum ile karşılaşmıştır. Farklı toplumlardaki bu farklı tanımların, çıkıs noktası biyolojik olarak ayırt edilebilen cinsiyet kavramıdır. Fakat farklı iki kültürün cinsiyet kavramını tanımlama anlamında ortak bir noktada buluşabileceklerini söylemek pek mümkün değildir. Her toplumun kendi kültürüne göre tanımladığı cinsiyet kavramından yola çıkarak, cinsiyetin sadece biyolojik farklılık olmadığını, kültürel öğelerin cinsiyeti şekillendirmede önemli bir rol oynadığını söylenebilir ${ }^{1}$.

Toplumsal cinsiyet; biyolojik cinsiyetten farklı olarak, toplumsal ve kültürel olarak belirlenir. Dolayısıyla, içeriği toplumdan topluma olduğu kadar tarihsel olarak da de-

1 Ann Oakley, Sex, Gender and Society (London: Temple Smith, 1972), 159. 
ğişebilen "cinsiyet konumu” ya da "cins kimliği” olarak ifade edilebilir. Bu anlamıyla toplumsal cinsiyet, yalnızca cinsiyet farklılığını belirlemekle kalmaz, aynı zamanda da cinsler arasındaki eşitsiz güç ilişkilerini de belirleyen bir yol izler ${ }^{2}$. Kadınlığın ve erkekliğin, biyolojik farklılıkların yanı sıra toplumsal, kültürel ve tarihsel olarak belirlendiğinin altını çizmek için kullanılan toplumsal cinsiyet kavramı, cinsiyetin toplumsal olarak üretildiğine işaret eder. Cinsiyetin toplumsal olarak inşa edilmesi, aynı zamanda toplumsal cinsiyetin de değiştirilebildiğini gündeme getirmektedir ${ }^{3}$.

Toplumsal cinsiyet, birçok şekilde bireylerde kendisini dişa vurmaktadır. Bireylerin vücut şekli, kendilerini kabullendirme biçimleri hatta konuşma ve hareket şekilleri toplumsal cinsiyet kalıbıyla üretilir ${ }^{4}$. Bu kalıplar, toplumda etkin birer aktör olarak kadınların ve erkeklerin, gündelik yaşam pratikleri sonucu ortaya çıkan, eylemlerden oluşur. Toplumsal yaşamda üretilen, dinamik, dönüşen ve yaşayan ilişki örüntülerinden oluşan toplumsal cinsiyet kalıpları, günlük 'performanslar' olarak da tanımlanabilir. Performatif (söylemsel) olarak gündelik pratikler içinde kurulduğu için ve kurgu olması itibariyle sorgulanabilir, askıya alınabilir, reddedilebilir ya da yeniden oluşturulabilir. Kısacası, toplumsal cinsiyet, toplumsal yaşamda üretilmekte, tüketilmekte, dönüştürülmekte ve yeniden üretilmektedir ${ }^{5}$.

\section{Toplumsal Cinsiyet Kimliği, Rolleri ve Stereotipleri}

Toplumsal cinsiyet kimliği, bireylerin kadının, erkeğin ya da bu iki kategori dışındaki kimliklerin, içsel benlik bilinci olarak tanımlanabilir' ${ }^{6}$. Toplumsal cinsiyet bir sınıflandırma sistemi olup, vücutlara atfedilen karakteristikleri ve davranışları tanımlar. Bu karakteristikler ve davranışlar eril ve dişil olmaya dayandırılmaktadır ${ }^{7}$. Toplumsal cinsiyet kimliği, bireylerin biyolojik cinsiyetlerine uygun ve tutarlı olma şartıyla belirlenir. Bir kadından, kadınsı davranışlar sergilemesi beklenirken, bir erkekten de erkeksi davranışlar sergilemesi beklenir ${ }^{8}$. Cinsiyet terimi ile çoğu zaman biyolojik cinsiyet farklılığ kastedilirken, cinsiyet kimliğinde ise cinsiyetle ilgili psikolojik özellikler ön plana çıkarılmaktadır. Bireylerdeki cinsiyet kimliğinin ortaya çıkışı, nasıl kadın ve erkek olunacağının anlaşılmasıyla başlar. Toplum tarafından cinsiyetlerine uygun görülen normları ve beklentileri öğrenen bireyler, kimliklerini (erilliği ve dişiliği) kültürel kalıplara göre sosyal olarak inşa ederler. Dişilik; yumuşaklık, konuşkanlık, anlayışlılık, naziklik, diğerlerinin duygularının farkında olmak, dinine bağlılık, dış görünüşüyle ilgili olma, alışkanlıklarında düzenlilik, güven duyma ihtiyacı, duygularını kolay ifade edebilme, sanat ve edebiyattan hoşlanan ve sosyal bilimlerde yönelim olarak kabul edilir. Erillik ise; saldırganlık, bağımsızlık,

2 Fatmagül Berktay, Tek Tanrılı Dinler Karşısııda Kadın (İstanbul: Metis Yayınları, 2000), 16.

3 Sevda Alankuş, “Önsöz: Neden Kadın Odaklı Habercilik?”, Habercinin el kitabı: Kadın Odaklı Habercilik, drl., Sevda Alankuş (İstanbul: IPS, 2007), 28-29.

4 Judith Butler, Undoing Gender (Newyork: Routledge, 2004).

5 Erol Maral, "İktidar, Erkeklik ve Teknoloji”, Toplum ve Bilim Dergisi 101 (2004), 128.

6 Riki Wilchins, “Queerer Bodies”, Gender Queer: Voices From Beyond The Sexual Binary, ed., Joan Nestle, Clare Howell ve Riki Wilchins (Los Angeles: Alyson, 2002).

7 Jamison Green, Becoming A Visible Man (Nashville: Vanderbilt University Press, 2004).

8 Julie L. Nagoshi, Craig T. Nagoshi ve Stephan/ie Brzuzy, Gender and Sexual Identity (New York: Springer,2004), 5. 
duygusal olmama veya gizleme, nesnel davranma, kolay etkilenmeme, bilimsel olma, fen bilimlerine eğilimli, kolay heyecanlanmama, rekabetçi, mantıklı, kamusal alana yönelik, başarılı, kuvvetli, lider gibi davranabilme, çalışma hayatında başarılı olmak gibi özellikleri içerir 9 .

Toplumsal cinsiyet rolleri, çeşitli ilgi alanlarını, sorumlulukları imkânları, limitleri ve davranışları dikte eden toplumsal normlar, kurallar ve standartlar olarak tanımlar. Toplumsal cinsiyet rollerinin yapısı çeşitli bölümlerden oluşur. Kişinin kıyafet seçiminden iş seçimine kadar günlük hayatta etkili bir rol oynar. Bireyler sosyal hayatta nasıl davranacaklarını ve kabul gören davranışların hangileri olacağını, cinsiyetlerinden öğrenirler. Bireyler içinde bulundukları kültürün toplumsal cinsiyet rollerini ister kabul etsin, ister etmesin, bu roller sosyal organizasyonlarda güçlü anlamlar içerir ve topluma önemli ölçüde etki eder. Bu nedenle, insanlar kaçınılmaz olarak geleneksel ve kalıplaşmış toplumsal yargıları, seçtikleri belirli toplumsal cinsiyet rollerine bakmaksızın benimserler ${ }^{10}$. Toplumsal cinsiyet rolleri, kültür tarafından tanımlanmış, sınırı çizilmiş kadın ve erkeğe ait davranışlar bütünüdür. Sosyo-kültürel bir süreç olan toplumsal cinsiyet rollerinin hayata geçirilmesi rolün öğrenilmesi, toplumsallaşma, içselleştirme gibi süreçleri içermektedir. Bu üçlü ilişkinin devamlılığını ve yeniden üretilmesini sağlayan da anne, baba, aile, öğretmenler, arkadaş grupları ve medya gibi ilişki örüntüleri ve kurumlardır ${ }^{11}$.

Toplumsal cinsiyet stereotipi ile üretilen inanışlar, kadın ve erkeği tanımlar, hatta nasıl olması gerektiklerini de belirler. Stereotipler, genel toplumsal cinsiyet inanç sisteminin bir parçasıdır ve cinsiyet algılarını etkiler. Bu inanç sistemi, toplumsal beklentilerin büyük bir parçası olarak nakledilir ve cinsiyetlere göre uygun rolleri belirler. Aile, medya ve akranlar, kadın ve erkeğin kim olduğuna ve nasıl olması gerektiğinin belirlenmesinde büyük paya sahiplerdir. Toplumsal cinsiyet stereotiplerinin dayanıklılık değerini arttırmak için, stereotiplerin erken yaşlarda nasıl geliştirildiğini ve çocuklar tarafından cinsiyetlere ait uygun davranışların nasıl ölçüldüklerini dikkate almak gerekir. İki aylık bir bebek, kadın ve erkek sesini ayırt edebilir. Altıncı ayda kadın ve erkek yüzleri arasındaki farklılıkları ayırt edebilir. İki ya da üç yaşına geldiğinde ise kendi cinsiyetine uygun olarak üretilen oyuncağın hangisi olduğunu ve hangi aktivitelerin cinsiyetine uygun olabileceğini bilir. Bu özellikler, nadiren farkl1lik gösterebilir ${ }^{12}$.

\section{Cinsiyete Dayalı Ayrımcılık}

Cinsiyetçilik terimi negatif bir anlam yüklenerek, cinsiyete dayalı ayrımcılık terimi ile aynı anlamda kullanılmaktadır. Cinsiyete dayalı ayrımcılık; kadın ve erkeğin toplumsal cinsiyet kalıp yargılarından oluşan, özünde kadın cinsine yönelik ayrımcıl1-

9 Aysel Günindi Ersöz, “Türk Atasözleri ve Deyimlerde Kadına Yönelik Toplumsal Cinsiyet Rolleri”, Gazi Üniversitesi Türkiyat Dergisi 6 (2010), 170.

10 Joy L. Johnson, Lorraine Greaves ve Robin Repta, Better Science With Sex and Gender: A Primer For Health Research (Canada: Women's Health Research Network, 2007), 23.

11 Robert William Connell, Toplumsal Cinsiyet ve İktidar: Toplum, Kişi ve Cinsel Politika, çev., Cem Soydemir (İstanbul: Ayrıntı Yayınları, 1998), 79.

12 Encyclopedia of Women and Gender, Judith Worell (California: Academic Press, 2002), 562-563. 
$\breve{g ̆}_{1}$ ifade etmektedir. Erkek egemen toplumlarda kadını erkeğe göre ikincil ve aşağı konuma oturtan bütün tutum, davranış ve etkinlikler ile bunları yeniden üretmek için bütün kurumsal ve ideolojik olanakların kullanılması, cinsiyet ayrımcılığı olarak adlandırılabilir ${ }^{13}$.

Sancar, erkek egemenliğine dayalı toplumsallığı anlamak için iki farklı boyuta bakmanın önemini vurgular ${ }^{14}$. İlki, erkekler ve kadınlar arasında tahakküme dayalı eşitsiz ilişkilerin nasıl yaratıldığını anlamaktır. İkincisi, bazı toplumsal davranış, işlev, konum ve pratiklerin eril, bazılarının nasıl dişil anlamlar taşıdığını anlayabilmektir. Aynı işi yapan kadınların erkeklerden daha az kazanması ya da şiddetin genellikle erkeklerden kadınlara yöneltilen bir unsur olması ilk sorunun bağlamını oluşturur. Makine kullanımının eril, ev temizlemenin dişil anlamlar taşıdığ 1 ve erkeklerin yaptığ 1 işin daha değerli olduğunu söylemek ise ikinci sorunun bağlamını oluşturarak cinsiyet eşitsizliklerinin dayandığı güçleri anlamak açısından önem arz etmektedir. Cinsler arası eşitsizlik yaratan somut iktidar ilişkileri kadar toplumsal ilişkilerin kendisini cinsiyetlendiren ve diğer toplumsal eşitsizlikleri de cinsiyet eşitsizlikleriyle ilişkili hale getiren cinsiyet düzeni ya da cinsiyet rejimi, cinsiyete dayalı eşitsizlikleri besler ve bu eşitsizlikleri normalleştirir.

\section{Medyanın Cinsiyet Söylemi}

Medya; yönlendirme, düzenleme, iktidar ilişkilerini yerleştirme ve pekiştirme özellikleriyle iktidar ilişkilerinin normalleşmesini ve rızanın sağlanmasında önemli bir işleve sahiptir. Medya ayrıca, eşitsiz güç ve iktidarı söylemsel bazda ele alıp eleştirerek, dalga geçerek ve tekrarlayarak sıradanlaştırmaktadır. Böylece erkek iktidarı medya tarafından imgesel öğeler ve diğer pratikler aracılığıyla üretilip pekiştirilmektedir ${ }^{15}$. Bir kurum fonksiyonu olarak eşitsizliğin sağlanması adına medya, ilk olarak farklılıkları yaratır ve bu farklılıkları kendisinin ürettiğini gizler. Bu yöntemle yaratılan farklılıkların hayatın doğal bir parçası gibi görünmesini sağlar. Farklı gruplara farklı mesajlarla iletilen bu toplumsal cinsiyet farklılıkları, daha önceden oluşturulmuş farklılıkları destekleyici niteliktedir ${ }^{16}$.

Toplumsallaşmanın öğrenilmesinde sadece aile, arkadaş ve sosyal çevre etkili değildir. Toplumun hizmetine sunulan tüm kurum ve nesneler özellikle de medya, cinsiyete ve toplumsal cinsiyet rollerine ilişkin kalıp yargıları yeniden üreterek dayatmaktadır. Örneğin; televizyon reklamlarında uzman tavsiyelerinde bulunan en akıllı, en bilgili kişi olarak gösterilen erkekler ve bu erkeklerin ev işlerinden sorumlu, evine düşkün olarak gösterilen, doğası gereği de böyle bir konumu hak ettiği iddia edilen kadınların yaşamlarını izleriz ${ }^{17}$. Medya kadınlarla ilgili stereotip imajlar kullanmak-

13 Nilüfer Timisi, Medyada Cinsiyetçilik (Ankara: KSSGM Yayınları, 1997), 24.

14 Serpil Sancar, Erkeklik: Imkansiz İktidar, Ailede, Piyasada, ve Sokakta Erkekler (İstanbul: Metis Yayınları, 2013), 175.

15 Gönül Demez, “Sanal Dünyanın Kişisel Alanı: Bir Sosyal Paylaşım Ağı Olarak Facbook’ta Erkek(lik) Tartışmaları”, Medyada Hegemonik Erkek(lik) ve Temsil, Ed., İlker Erdoğan (İstanbul: Kalkedon Yayınları, 2011), 328-329.

16 Michael Kimmel, The Gendered Societ (Newyork: Oxford Üniversity Press, 2011), 290.

17 Pınar Seden Meral, "Erkek Hegemonyasının (Yeniden) Üretimi: Dergi Reklamlarında Hegemonik Erkekliğin Temsili”, Medyada Hegemonik Erkek(lik) ve Temsil, Ed., İlker Erdoğan (İstanbul: Kalkedon Yayınları, 2011), 299. 
tadır. Bu imajlar kadınları ikinci planda tutan, erkek bağımlılığına vurgu yapan bir ideolojiye hizmet edip, kadınların eve ve aileye ilişkin rollerini ön plana çıkarmaktadır. Bu türden bir toplumsal cinsiyete ilişkin bakış açısının cinsiyet eşitliğinin gelişimini engelleyici bir işlev gördügü kabul edilmektedir ${ }^{18}$. Medya kitlelere normal bir erkeğin imajını, sahip olması gereken fikirleri, nasıl davranması ve görünmesi gerektiği mesajlarını aktarır. Kültürel beklentiler, dergi, film, spor programları, televizyon programları ve reklamlar aracığıyla aktarılır. Normal erkek profilinin hangi özelliklere sahip olması gerektiğini belirleyen medya, ideal erkek olmanın kriterlerini de kitlelere aktarmış olur. Medyanın profilini çizdiği ideal erkek, sportif faaliyetlere katılmalı enerjisini başarı ve kariyerine yönlendirmeli, entelektüel ve fiziksel yeteneklerini geliştirmeli, rekabetçi, yapıcı, maceracı, bağımsız, uzman, güçlü, sert, cinsel olarak saldırgan, duygularını kontrol altında tutan olmalıdır ${ }^{19}$.

\section{Türk Spor Basının Habere Bakış Açısı}

Spor, toplumsal yapının önemli ve ayrılmaz bir parçası olma özelliklerinin yanı sıra, toplumsal yapı içerisinde yer alan bireylerin, toplumsal yapıyı şekillendirmede etkili olabilecek seçimleri yapmalarında, toplumsal ve kültürel anlamları, değerleri ve sembolleri öğrenmelerinde önemli bir işleve sahiptir ${ }^{20}$. Sporun içerisinde bulunduğu toplum yapısından etkilendiği ve aynı zamanda da bu toplumsal yapıyı etkilediğini düşünürsek, spor basınının bu etkileşimde önemli işlevlerinin olduğunu söylenebilir. Toplumda egemen olan ideolojilerin ve kalıp yargıların en fazla karşılık bulduğu, sözünün geçtiği alanlardan biri de spor alanıdır. Egemen ideolojinin şekillendirdiği toplum yapısı spor alanına da etki etmektedir. İçerisinde bulunan toplumun cinsiyetlerden beklentileri ve cinsiyete dair yargıları spor alanında faaliyet gösteren her bireye ve kuruma izlemeleri gereken yolun rehberliğini yapmaktadır. Yaşamın her alanı gibi spor da bir çekişme alanıdır. Güce ve sert şartlara dayanmayı esas kılan spor, diğer toplumsallaşma alanları gibi iktidar ilişkilerinden bağımsız değildir.

Türk spor basını, okuyucuların ilgisini çekmek ve heyecanı arttırmak için yazı dilini etkili bir haber diline dönüştürür. Sporun doğasından kaynaklanan kazanma hırsı, heyecan ve rekabet gibi insani duygular kelimelere dökülerek okuyucuya etki etmek istenilir. Spor basınında başarıyı temsil eden kelimeler; zafer, ezmek, parçalamak, dağıtmak vb. gibi kelimelerdir. Spordaki rekabetin dayattığı başarıya ulaşma zorunluluğu spor basınının da haber dilinde bu kavramları kullanmasına yol açmaktadır. Diğer bir kavram yumağı ise militarist kavramlardır. Sporun kazanma amacıyla yapılıyor olması hatta bu amaç dışındakilerin spordan sayılmaması, sporu bu tanımıyla işleyen spor basınının savaşa hazırlanan "silahlı kuvvetleri" motive etme amacı taşıyan kavramları kullanmasını meşru kılar. Sporun, savunma ve hücum amaçlı stratejileri, güce dayalı taktiksel gereklilikleri ve bunların katı bir disiplin içinde yapılma

18 Roger Smith, “İmgeler ve Eşitlik: Kadınlar ve Ulusal Basın”, Medya, Kültür, Siyaset, dzl., Süleyman İrvan (Ankara: Ark, 1997).

19 Serdar Kaypakoğlu, Toplumsal Cinsiyet ve İletişim, (İstanbul: Naos Yayınları, 2003), 104.

20 İlknur Hacısoftaoğlu ve Canan Koca, "Spor Medyasında Hegemonik Erkekliğin (Yeniden) Üretimi: 'Delikanlı Gibi Yaşayın, Delikanlı Gibi Oynayın”, Medyada Hegemonik Erkek(lik) ve Temsil, Ed., İlker Erdoğan (İstanbul: Kalkedon Yayınları, 2011), 70. 
şartı, yine silahlı kuvvetler ile benzerlik gösterir. Kısaca spor basınının haber dilini oluşturan öğeler spor kavram ve söz dizilimleri, ulusal semboller, deyimler, militarist kavramlar, patolojik kavramlar, doğa kavramları, ekonomi kavramları, mitolojik kavramlar, argo sözcük ve söz dizilimleri biçimindedir ${ }^{21}$. Medya ve özellikle spor basınını cinsiyetçi söylemlerinin kaynağını içinde yaşadığımız toplumun dili olan Türkçeden alır. Dilimize yerleşmiş olan deyimler, deyişler ve atasözleri toplumsal cinsiyetin yüklediği anlamları taşır. Dilimiz, dilbilgisi seviyesinde olmasa da atasözleri ve deyimlerle cins ayrımını yansıtır. Kadının toplumdaki ve ailedeki konumu, yükümlülükleri ve özellikleri eğretilemeler ve ötekileştirmelerle açıkça ifade edilmektedir. Atasözlerimiz ve deyimlerimiz kadın ve erkeği birbirinin özellikleri ile betimlemektedir ${ }^{22}$.

\section{Fanatik ve Fotomaç Gazetesi Haberlerinin Analizi}

Türk spor basının en köklü ve en çok okura ulaşan gazeteleri olmaları nedeniyle çalışmanın araştırma bölümü için seçilen Fotomaç ve Fanatik gazetelerinin 2013, 2014 ve 2015 yıllarına ait birer haftalık sayıları, Türk spor basının cinsiyete dayalı haber politikasını ortaya koyması ve genel bir görünüm vermesi amacıyla rastgele seçilmiştir. 2013 yılının 26. haftasındaki, 2014 yılının 16. haftasındaki ve 2015 yılının 28. haftasındaki Fotomaç ve Fanatik gazeteleri incelenmiştir. Türk spor basınının habere ilişkin genel bir görümünü aktarması amacıyla içeriğe dair bilgiler verilecektir. Bu tez kapsamında incelenen gazete sayılarında yer alan ve cinsiyet ayrımcılığı öğeleri içeren haberlerin analizinde eleştirel söylem çözümlemesi uygulanmıştır. Eleştirel söylem çözümlemesinin sağlayacağı yöntemsel metotların 1şı̆̆ında, ideolojik yapının ürünü olan ve söylemler aracılığıyla dile, dolayısıyla topluma yerleşen cinsiyetçi ifadelerin spor basınındaki kullanımına Fanatik ve Fotomaç gazetesindeki haberler aracılığıyla değinilecektir.

\section{Haber ve Söylem}

Haber gerçek olaylara dayansa da neticede olayı izleyen ve aktaran gazetecinin zihinsel sürecinden geçerek işlenir ve okuyucuya sunulur. Habere konu olayı, olguyu haberin hammaddesi olarak düşündüğümüzde, bu hammadde gazetecinin bilişsel alg1, yorum ve değerlendirme süzgeçlerinden geçerek habere dönüştürülür. Haber metni gazetecinin metni oluşturma aşamasındaki etkileri nedeniyle aslında gerçek olayın birebir yansıması değildir. Dolayısıyla haberler gerçek olaylara dayansalar bile, olayları saf ve pür bir şekilde aktaramazlar. Haberler ancak gerçek olaylardan beslenmiş kurmaca anlatılar olabilir. Van Dijk’e göre, bu kurmaca metnin çözümlenmesi aşamasına mutlaka haberi üretenin de eklemlenmesi gerekir²3. Söylem çözümlemesi, metindeki içeriğin analiz edilmesi, metne içerilmiş anlamların, kullanılan dilsel Birimler(sözcükler, tümceler vb.) aracılığıyla incelenmesidir. Söylem çözümlemesi, metinde kullanılan dilin açık anlamlarına bakmakla yetinmez, sözcüklerin, terimle-

21 A. Yalçın Kaya, “Spor Basınında Dil Kullanımı”, Selçuk Üniversitesi İletişim Fakültesi Dergisi 2 (2002), 143148.

22 Nuray Alagözlü, Dil ve Cins: Türkçe Atasözlerinde ve Deyimlerde Kadın Üzerine Eğretilemeler ve ToplumBilişsel Yapı, International Journal of Central Asian Studies 13 (2009), 41-43.

23 Teun A. Van Dijk, Text and Context (London: Longman, 1997). 
rin ve kavramların içerisinde üretildikleri ilişkilere, tarihsel süreçlere, paradigmaya da bakarak inceleme konusu kapsamına dahil eder. Van Dijk’in söylem çözümleme yönteminin esaslarını vurgulayacak olursak; metnin öncelikle ne söylediği, ne ile ilgili olduğu ve ne anlama geldiği üzerinde durulmalıdır ${ }^{24}$.

Eleştirel söylem çözümlemesi, söylem çözümlemeleri arasında disiplinler arası yaklaşımlarla gelişen ve ideoloji yüklü olduğu iddia edilen dilsel yapıları dil biliminin yöntemlerinden yararlanarak sistemli bir şekilde açıklamayı amaçlayan bir çözümleme yöntemidir. İdeoloji, dili kontrol altında tutan bir güçtür. İdeolojinin hâkimiyeti altında olan söylem, hem zihni temsil eden hem de zihni yönlendiren bir güç olarak ortaya çıkmaktadır. Bu nedenle eleştirel söylem çözümlemesi, herhangi yazılı ya da sözlü metnin arka planında hangi ideolojik etmenlerin rol oynağını ve söylemin bu etmenler doğrultusunda nasıl kurgulandığını anlayabilmek, söylemin yanlı ya da nesnel olup olmadığını ayırt edebilmek açılarından önem arz eder. Kısacası, eleştirel söylem çözümlemesi "bakmak” ve "görmek” arasındaki farkın bilimsel yöntemleştirilmesi olarak da düşünülebilir ${ }^{25}$.

\section{Araştırmanın Bulgu ve Analizleri}

\section{A. İçeriğe Dair Veriler}

Yapılan araştırma kapsamında incelen gazetelerin 2013, 2014 ve 2015 yıllarının birer haftalarındaki sayılarına ait haberlerin, spor dallarına göre dağılımı, cinsiyetlere göre dağılımı ve bu haberlerde kullanılan fotoğrafların cinsiyetlere göre dağılımı aşağıdaki tablolarda gösterilmektedir. Türk spor basınının habere bakış açısını, nicel verilere dayandırıp ortaya koymayı amaçlayan içeriğe dair çözümleme, çalışma kapsamında uygulanacak olan söylem çözümlemesinin destekleyicisi niteliğindedir. Gazetelerin yapmış oldukları haberlerin, sporun hangi alanlarını, hangi yoğunluk oranlarında kapsadığını bilmek, haber dilindeki ifadelerin temelini oluşturan yapıları anlamak açısından önemlidir.

Tablo 1. 2013 Yılının 26. Haftasına Ait Gazete Haberlerinin Spor Dallarına göre Dağılımı

\begin{tabular}{|c|l|r|r|r|r|}
\hline \multicolumn{1}{|c|}{ Gazete } & \multicolumn{2}{c|}{ Fotomaç } & \multicolumn{2}{c|}{ Fanatik } \\
\cline { 2 - 6 } & İncelenen Spor Dalları & Sayısı & Yüzde (\%) & Sayısı & Yüzde (\%) \\
\cline { 2 - 6 } & Futbol & 490 & 82,77 & 525 & 76,53 \\
\cline { 2 - 6 } & Basketbol & 19 & 3,21 & 37 & 5,39 \\
\cline { 2 - 6 } & Voleybol & 14 & 2,36 & 9 & 1,31 \\
\cline { 2 - 6 } & Diğer Spor Dalları & 54 & 9,12 & 99 & 14,43 \\
\cline { 2 - 6 } & Organizasyon Konuları & 15 & 2,53 & 16 & 2,33 \\
\cline { 2 - 6 } & Toplam Sayı & 592 & 100 & 686 & 100 \\
\hline
\end{tabular}

24 Nazife Güngör, İletişim, Kuramlar ve Yaklaşımlar (Ankara: Siyasal Kitapevi, 2013), 247-250.

25 S. Nalan Büyükkantarcıŏlu, "Söylem İncelemelerinde Eleştirel Dilbilimsel Boyut: Eleştirel Söylem Çözümlemesi ve Ötesi”, Haberi Eleştirmek, Ed., Ömer Özer (Konya: Litaratürk, 2002), 
2013 yılının 26. haftasındaki Fotomaç gazetesinde yer alan toplam 592 haberin 490 'nını futbolla ilgili haberler oluşturmaktadır. 19 haber basketbolla, 14 haber voleybolla, 54 haber diğer spor dallarıyla ve 15 haber de organizasyon konularıyla ilgilidir. Haberlerin yüzdesel oranlarına bakıldığında, futbolun diğer spor dallarına göre üstünlük sağlamaktadır. Fanatik gazetesinde ise yer alan 686 haberin 525'i futbolla, 19'u basketbolla, 14'ü voleybolla, 54'ü diğer spor dallarıyla ve 15’i de organizasyon haberleriyle ilgilidir. Yüzdesel oranlara göre futbol yine en büyük yüzdesel orana sahiptir.

Tablo 2. 2014 Yılının 16. Haftasına Ait Gazete Haberlerinin Spor Dallarına göre Dă̆ılımı

\begin{tabular}{|l|l|r|r|r|r|}
\hline \multicolumn{1}{|c|}{ Gazete } & \multicolumn{2}{c|}{ Fotomaç } & \multicolumn{2}{c|}{ Fanatik } \\
\cline { 2 - 6 } & İncelenen Spor Dalları & Sayısı & Yüzde (\%) & Sayısı & Yüzde (\%) \\
\cline { 2 - 6 } & Futbol & 555 & 93,91 & 475 & 88,79 \\
\cline { 2 - 6 } & Basketbol & 22 & 3,72 & 38 & 7,10 \\
\cline { 2 - 6 } & Voleybol & 7 & 1,18 & 4 & 0,75 \\
\cline { 2 - 6 } & Diğer Spor Dalları & 3 & 0,51 & 15 & 2,80 \\
\cline { 2 - 7 } & Organizasyon Konuları & 4 & 0,68 & 3 & 0,56 \\
\cline { 2 - 6 } & Toplam Sayı & 591 & 100 & 535 & 100 \\
\hline
\end{tabular}

2014 yılının 16. haftasındaki Fotomaç gazetesinde yer alan toplam 591 haberin 555'ini futbolla ilgili haberler oluşturmaktadır. 22 haber basketbolla, 7 haber voleybolla, 3 haber diğer spor dallarıyla ve 4 haber de organizasyon konularıyla ilgilidir. Haberlerin yüzdesel oranlarına bakıldığında futbol, tüm haberler içerisinde en yüksek orana sahiptir. Fanatik gazetesinde ise yer alan 535 haberin $475^{\prime}$ ini futbol, 38'ini basketbol, 4'ünü voleybol, 15'ini diğer spor dalları ve 3'ünü de organizasyon konulu haberler oluşturmaktadır. Futbol en yüksek yüzde ile yine ilk sıradadır.

Tablo 3. 2015 Yılının 28. Haftasına Ait Gazete Haberlerinin Spor Dallarına göre Dă̆ılımı

\begin{tabular}{|l|l|r|r|r|r|}
\hline \multicolumn{1}{|c|}{ Gazete } & \multicolumn{2}{c|}{ Fotomaç } & \multicolumn{2}{c|}{ Fanatik } \\
\cline { 2 - 6 } & Incelenen Spor Dalları & Sayısı & Yüzde (\%) & Sayısı & Yüzde (\%) \\
\cline { 2 - 6 } & Futbol & 460 & 94,65 & 524 & 91,45 \\
\cline { 2 - 6 } & Basketbol & 8 & 1,65 & 20 & 3,49 \\
\cline { 2 - 6 } & Voleybol & 5 & 1,03 & 2 & 0,35 \\
\cline { 2 - 6 } & Diğer Spor Dalları & 12 & 2,47 & 25 & 4,36 \\
\cline { 2 - 7 } & Organizasyon Konuları & 1 & 0,21 & 2 & 0,35 \\
\cline { 2 - 6 } & Toplam Sayı & 486 & 100 & 573 & 100 \\
\hline
\end{tabular}

2015 yılının 28. haftasındaki Fotomaç gazetesinde yer alan 486 haberin 460'ını futbolla ilgili konular oluşturmaktadır. 8 haber basketbolla, 5 haber voleybolla, 12 haber diğer spor dallarıyla ve 1 haber de organizasyon konularıyla ilgilidir. En çok yüzdeye 
sahip olan spor dalı futbodur. Fanatik gazetesinde ise yer alan 573 haberin 524 'ünü futbol, 20'sini basketbol, 2'sini voleybol, 25'ini diğer spor dalları ve 2'sini de organizasyon haberleri oluşturmaktadır. Yüzdesel oranlamada futbol yine ilk sıradadır.

Tablo 4. Toplam Haber Sayısı

\begin{tabular}{|c|r|r|r|}
\hline Toplam Haber Sayıları & Fotomaç & Fanatik & Toplam \\
\hline 2013 & 592 & 686 & 1278 \\
\hline 2014 & 591 & 535 & 1126 \\
\hline 2015 & 486 & 573 & 1059 \\
\hline Toplam & 1669 & 1794 & 3463 \\
\hline
\end{tabular}

Fotomaç gazetesi 2013 yılının 26. Haftasında 592 habere sahipken Fanatik gazetesi 686 habere sahiptir. Fotomaç gazetesi 2014 yılının 16. Haftasında 591 haber üretirken, Fanatik gazetesi 535 haber üretmiştir. 2015 yılında ise Fotomaç gazetesi 486 haber sayısına ulaşırken, Fanatik gazetesi 573 haber sayısına ulaşmıştır. Üç ayrı yılın üç ayrı haftasındaki Fotomaç ve Fanatik gazetelerine ait sayılarda toplam 3463 haber yer almıştır.

Grafik 1. 2013-2014-2015 Yillarına Ait Fanatik ve Fotomaç Gazetesi Sayılarında Incelen Toplam Haberlerin Spor Dallarına göre Dağılımı

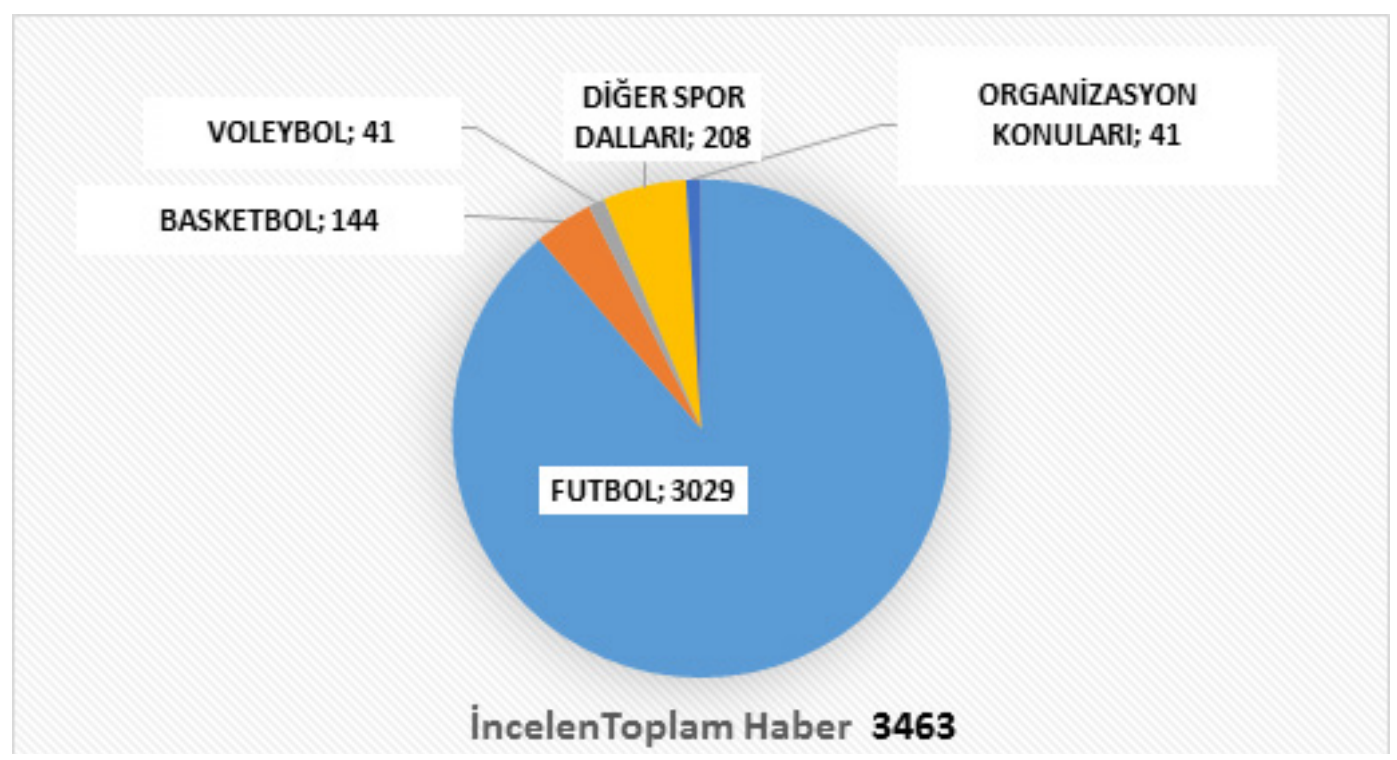

2013, 2014 ve 2015 yıllarına ait Fanatik ve Fotomaç gazetelerinde incelenen toplam 3.463 haberin 3029'u futbolla, 208'i diğer spor dallarıla, 144'ü basketbolla, 41'i voleybolla, 41'i organizasyon konularıyla ilgili haberlerdir. Yıllara ait haber sayıları dikkate alındığında futbolun en çok haberleştirilen spor dalı olduğu görülmektedir. Üç yılın toplamına bakıldığında futbolun, tüm spor dalları üzerinde bir yere sahip olduğu görülmektedir. 
Tablo 5. Kadınlarla İlgili Haberlerin Yıllara Göre Dă̆ılımı

\begin{tabular}{|c|r|r|}
\hline Kadınlarla İlgili Haber Sayıları & Fotomaç & Fanatik \\
\hline 2013 & 44 & 64 \\
\hline 2014 & 22 & 25 \\
\hline 2015 & 6 & 12 \\
\hline Toplam & 72 & 101 \\
\hline
\end{tabular}

2013 yılının 26. haftasındaki Fotomaç gazetesinin 592 haberinin 44’ü, Fanatik gazetesinin 686 haberinin 64'ü, 2014 yılının 16. haftasındaki Fotomaç gazetesinin 591 haberinin 22'si, Fanatik gazetesinin 535 haberinin 25'i, 2015 yllının 28. haftasındaki Fotomaç gazetesinin 486 haberinin 6'sı, Fanatik gazetesinin 573 haberinin 12'si kadinlarla ilgilidir.

Tablo 6. Fanatik ve Fotomaç Gazetelerinde Kullanılan Haber Fotoğraflarının Yillara ve Cinsiyete Göre Dağılımı

\begin{tabular}{|c|c|c|c|c|c|}
\hline \multirow{6}{*}{ 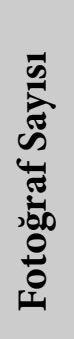 } & Gazete & \multicolumn{2}{|c|}{ Fotomaç } & \multicolumn{2}{|c|}{ Fanatik } \\
\hline & Yil & Kadın & Erkek & Kadın & Erkek \\
\hline & 2013 & 17 & 266 & 30 & 248 \\
\hline & 2014 & 11 & 254 & 22 & 219 \\
\hline & 2015 & 4 & 225 & 5 & 256 \\
\hline & Toplam & 32 & 745 & 57 & 723 \\
\hline
\end{tabular}

2013 yılının 26. haftasında Fotomaç gazetesinde 17 tane kadın, 266 tane de erkek fotoğrafı yer almıştır. Fanatik gazetesinde ise 30 tane kadın fotoğrafı kullanılırken 248 tane de erkek fotoğrafı kullanılmıştır. 2014 yılının 16. Haftasında Fotomaç gazetesinde 11 tane kadın fotoğrafına yer verilirken, 254 tane de erkek fotoğrafı yer verilmiştir. Fanatik gazetesinde ise 22 tane kadın fotoğrafı yer alırken, 219 tane de erkek fotoğrafı gazetede yer almıştır. 2015 yılının 28. Haftasında Fotomaç gazetesinde 4 tane kadın fotoğrafı kullanılırken, 225 tane de erkek fotoğrafı kullanılmıştır. Fanatik gazetesinde ise 5 tane kadın fotoğrafı kullanılırken, 256 tane de erkek fotoğrafı gazete haberlerinde kullanılmıştır. Üç ayrı yılın toplamında Fotomaç gazetesinde 32 tane kadın, 745 tane erkek fotoğrafına yer verilirken, Fanatik gazetesinde 57 tane kadın, 723 tane kadın fotoğrafı kullanılmıştır. İki gazetenin 2013, 2014 ve 2015 yıllarına ait belirli haftalarındaki sayılarının toplamında 89 tane kadın fotoğrafı kullanılırken, 1468 tane de erkek fotoğrafının kullanıldığı görülmüştür.

Tüm bu içeriğe dair analiz verileri göstermektedir ki, erkeklerin en çok ilgi gösterdiği spor dalı olan futbol, haberlerde en çok kaleme alınan konu olmuştur. Yüksek performansa ve ileri derecede beden gücüne dayanan bir spor dalı olmasılya, erkek egemenliğinin hakim olduğu toplum yapısında futbol, erkekliğin ispatlanma alanı olarak da medya söylemine yansımaktadır. Kadınların daha az beden gücüne dayanan spor dallarına yönlendirilmesiyle spordaki hakimiyetin tek sahibi olan erkekler, spor basınında da hakimiyetlerini ilan etmişlerdir. Haber sayılarına bakıldığında, 
erkek haberlerinin neredeyse tamamını futbol haberleri oluştururken, kadın haberleri diğer spor dallarını çerçevesinde oluşmuştur. Sayısal anlamda kadın haberlerine ezici bir üstünlük kuran erkek haberleri, kadınların spor alanlarında olduğu gibi spor basınında da ikincil konumunu beslemektedir. Haber görselleri incelendiğinde, sayısal üstünlüğünün ötesinde, erkek fotoğrafları, erkek bedeninin gücünü simgeleyen güçlü ve kaslı yapısıyla sunulmuştur. Kadınların fotoğrafları ise birlikteliği ve uyumu temsil eden takım fotoğrafları arasından seçilmiştir. Az sayıdaki kadın haberlerinin tamamına yakını iç sayfada haberleştirilmiş olup, birinci sayfadan verilen habere rastlanılmamıştır.

\section{B. Söyleme Dair Haber Çözümlemeleri}

\section{Cinsiyet Farklılı̆̆ına Göndermede Bulunan Kalıp İfadeler}

\section{a) Erkekliğin Yüceltilmesi}

Aşağıdaki haberler incelendiğinde, gazetelerde yer alan haberlerin erkek sporcularını ve takımlarını, kültürel yapı içerisinde değer atfeden takma isim ve sıfatlarla yücelttiği görülmektedir.

“Trabzonspor Takıma 'Abi’ Transfer Edecek” (Fotomaç, 2013) “2013-2014 Sivasspor-Yiğidolar” (Fanatik, 2013) "İkisinden Birisi Timsah Olacak" (Fanatik, 2013) "Paşa Scarione’yi Bitirdi” (Fanatik, 2013) “Gakgoş Sollied’i Bekliyor” (Fanatik, 2013) "Kral Geliyor" (Fotomaç, 2013) "Kaplana Bir Şey Olmaz" (Fanatik, 2014) "Abdurrahim Baba" (Fotomaç, 2014) "En Centilmen Gençlerbirliği” (Fotomaç, 2014) "Panzerler Cenk'in Peşinde” (Fanatik, 2015) "Aslana Göz Kırptı” (Fanatik, 2015) "Kara Kartal” (Fanatik, 2015) “12 Dev Adam Oluşuyor” (Fanatik, 2015) “Çaykur Rize’nin Yeni Şövalyesi” (Fotomaç, 2015) "Alemin Kralı Geliyor” (Fanatik, 2015) "Furtına Başladı: 5-0" (Fanatik, 2015) "Pitbull Melo İnter'e” (Fotomaç, 2015)

Futbol kulüplerinin ve erkek sporcuların “aslan”, "kartal”, “fırtına”, “panzerler”, "gakgoş”, “yiğido”, "paşa”, "timsah”, "pitbull” gibi lakapları Türk spor basınında sıkça rastlanan metafor kullanımına örnek olarak gösterilebilir. Hayvan benzetmeleriyle, hayvanların yırtıcı gücüne ve kuvvetine, yerel konuşma diline özgü tabirlerle, erkekliğin ve delikanlılığın özelliklerine ve doğa olaylarına dayanan benzetmelerle, doğanın güçlü ve vahşi yapısına göndermelerde bulunulmaktadır.

Sporcuların ve spor alanında yöneticilik pozisyonlarında bulunan kişilerin, toplumda değer atfedilen "baba" ve "abi" gibi lakaplarla adlandırılması, bu kişilerin toplumsal kimliklerine göndermede bulunmaktadır. Ataerkil toplum yapısı içerisinde üzerine değerler yüklenen ifadelerin kullanılması, Türk spor basınındaki cinsiyetçi söylemin varlığını bir kez daha ortaya koymaktadır.

"Kral”, "paşa”, "şövalye” gibi eril yönetim sistemlerinin üst pozisyonlarında görev alan kişiler için kullanılan lakaplar ile erkek sporcuların bulundukları spor dalları içindeki önemli ve üst düzeydeki konumları vurgulanmaktadır. Gazete haberlerinde yer alan, erkekliği yücelten ifadelerin kullanımı, ataerkil toplum yapısının haber söylemi üzerinde erillik inşa edici etkisini göstermektedir. 
Takımların ve sporcuların "centilmenlik" gibi erkeklik özelliklerine vurgu yapan ifadelerle temsil ve takdir edilmesi, kadın sporcuların toplumda olduğu gibi Türk spor basınında da erkeklere göre ikincil pozisyonda bulunduklarının göstergesidir. Habere konu olan kadın sporcuların ve kadın takımlarının sıradanlaştırılan başarıları, eril söylem içerisinde takdir edilmezken erkek sporcuların sıradan başarıları ise övgü ve yüceltme öğeleri içeren ifadelerle haberleştirilmektedir.

Erkekliği yücelten lakapların spor basınında kullanımı hegemonik erkekliğin spor basını tarafından yeniden üretildiğini göstermektedir. Tek tip erkeklik yaratmayı hedefleyen, spor basınının cinsiyetçi lakap kullanımı, kadın sporcuları olduğu gibi egemen erkeklik değerleri dışında kalan erkekleri de değersizleştirmektedir. Gücün ve dayanıklılığın mükemmel bir beden yapısı ve sınırları zorlayan bir çalışma ile elde edilebileceği düşüncesi, bu şartları karşılayamayan ve egemen erkekliğin dışında kalan erkeklerin spordaki varlığını güçleştirmektedir.

\section{b) Kadınlığın Toplumsal Cinsiyet Özellikleriyle Temsili}

Aşağıdaki haberler incelendiğinde, kadınlığın fiziksel özelliklerine göndermede bulunan, toplumsal cinsiyet kalıplarının kadınlar için biçtiği rollere uygun niteleme sıfatları ve lakaplar spor basının kadınlarla ilgili haberlerinde sıkılıkla kullandığı ifadeler arasında yer almaktadır.

"Avrupa Sultanı Galatasaray" (Fanatik, 2014) "Altın Kızlar" (Fanatik, 2014) "Melekler Eczacıbaşı Önünde” (Fotomaç, 2014) "Periler, İspanya ile Liderlik Maçına Çıkıyor" (Fotomaç, 2013) “Genç Kızlar Sırbistan'ı Yendi” (Fanatik, 2013) "Yenge Milano’yu Özledi” (Fotomaç, 2013) "Kızlar Yarı Finalde” (Fanatik, 2013) "Filede Genç Kızlar Kazandı" (Fanatik, 2013)

"Sultanlar”, "Periler”, “Melekler”, “Genç kızlar”, "Altın kızlar” lakapları ile cinsiyetçi söylem okurlara aktarılmakta, farklı spor dallarında faaliyet gösteren kadın sporcular ve takımlar, kişi ya da takım isimleriyle değil de bu takma isimler ile temsil edilmektedir. A Milli Kadın Basketbol Takımı yerine "Potanın Perileri", A Milli Kadın Voleybol Takımı yerine "Filenin Sultanları", Fenerbahçe Kadın Voleybol Takımı yerine "Sarı Melekler" takma isimleri kullanılmaktadır. Öyle ki, zamanla haber diline yerleşen bu lakaplar, haberde kadın takımlarının gerçek isimlerini kullanmaya bile gerek birakmamaktadır.

Kadınların fiziksel gücünün değil de toplumsal cinsiyet kabullerinin kadınlıkla özdeşleştirdiği duygusallık, güzellik, zarafet gibi kadınlığın temel özellikleri gibi gösterilen bu özelliklerin spor basını tarafından ön plana çıkarılması erkek egemen ideolojiye hizmet etmekte ve kadınların toplum tarafından erkeklere göre ikincilleştirilen pozisyonlarını desteklemektedir. Takma isimlerin kaynağını oluşturan cinsiyetçi söylem, toplumsal cinsiyetin kadınlara atfettiği değerleri ve özellikleri yeniden üretmekte olup bu kalıp yargıları normalleştirmektedir. Bu kalıp ifadelerle kadınların yaptığı spor faaliyetlerinin güce ve dayanıklılığa dayanan koşulları görmezden gelinerek, spor faaliyetleri arasında kadınların "narin” bedenleri için uygun olduğu düşünülen spor dalları belirlenmektedir. 
Söylem ile topluma aktarılan kadınlar ile ilgili bu cinsiyetçi ifadeler, toplum tarafında karşılığını bulmakta, çift yönlü bir iletişim oluşturmaktadır. Haber başlığında ya da haber metninde geçen takma isimler ve sıfatlar, haberin fotoğrafı ile desteklenmektedir. Erkek sporcularla ilgili haberlerde, fiziksel gücü ön plana çıkaran fotoğraflarının kullanılmasının aksine kadınlığın uyumluluk, iyimserlik ve uzlaşmacılık gibi toplumsal kimlik özelliklerini vurgulamayı amaçlayan, sporcuların birlikte aynı karede yer aldığı fotoğraflar kullanılmaktadır.

"Genç kızlar" ve "Altın kızlar” ifadeleri kaynağını günlük konuşma dilinde sıkça rastladığımız "Kız gibi oynamak" ifadesinden almaktadır. Kadınların fiziksel güce dayanan oyunlarda başarısız olacağı düşüncesinin ifadeye yansıyan bu anlayış biçimi, kadın sporcuların, spor faaliyetleri öncesindeki ve sonrasındaki haberlerine de yansımaktadir.

Eril söylemin erkekliği güç ve dayanıklılık özellikleriyle yücelttiği, kadınları ise toplumsal kabullere dayanan dişil lakaplarla ve sıfatlarla nitelendirdiği haberler, spor basınında oldukça az yer verilen kadın sporcuların başarılarını gölgelemekte ve cinsiyetçi söylemin yaygınlaşmasına hizmet etmektedir.

\section{Erkek Bedeninin Gücü, Saldırganlık ve Kadına Verilen Değer}

Toplumsal cinsiyetin erkek bedeni ile özdeşleştirdiği, güçlü bir fizyolojik yapıya sahip olma, duygusal olarak sağlam gözükme gibi mükemmelliğe yakın anlamlar, aşağıdaki haberlerde görüldüğü üzere, Türk spor basını tarafından yaygın bir şekilde kullanılmaktadır.

\section{a) Erkek Bedeninin Gücü}

"Fırtına Turp Gibi” (Fotomaç, 2013) "Roket Adam Farfan" (Fanatik, 2013) "Ferrari Pilotu Gibiyim” (Fanatik, 2013) "İşte Adam Gibi Adam Slaven Bilic” (Fanatik, 2013) "Boğazın Yeni Boğası Loic Remy” (Fotomaç, 2015) “Güçlü Bal-Kes” (Fotomaç, 2015) "Van Persie Kaya Gibi” (Fanatik, 2015) "Makine Poldi” (Fanatik, 2015)

Haberlerini genellikle futbolla ilgili konulardan seçen spor basını, futbolun güce dayalı, dayanıklılık ve yüksek efor gerektiren şartlarını, erkek sporcular için bir gösteri alanı olarak görmektedir. İçinde yaşanılan ataerkil toplum yapısının etkisiyle, kimin daha güçlü, kimin daha dayanıklı, kimin daha çekişmeci olduğu futbol müsabakalarında gösterilen fiziksel performans ile belirlenmektedir.

“Turp gibi”, "kaya gibi”, "boğa gibi”, “makine gibi” sağlamlık ve dayanıklılık ile özdeşleştirilen benzetmeler, sporcuların güçlü bedenlerine göndermede bulunmakta, elde ettikleri başarıların temelinde bu özelliklerin yattığının mesajını vermektedir. Başarıyı fiziksel güce dayandıran bu benzetmeler, başarının tek yolunun güçlü bir beden yapısından geçtiğini söyleyerek kadınları ve diğer erkeklikleri yok saymaktadır. Erkek bedeninin sert ve yorucu antrenman koşullarına karşı adeta bir güç makinesi işlevi göstererek dayanması, olası beden sakatlıkları ihtimallerinin görmezden gelindiğinin göstergesidir. Her koşulda güçlü olmayı dayatan spor koşulları, bedensel sa- 
katlıkların, erkekler tarafından erkekliklerinin sakatlanması şeklinde algılanmasına neden olmaktadır.

"Roket adam" ve "Ferrari pilotu" benzetmeleri ise sporda fiziksel gücün yanında h1zın da önemli olduğunun altını çizmekte ve erkekliğin toplum tarafından övgüye değer bulunan yanlarını ön plana çıkarmaktadır. Yavaşlık gibi eksiklik olarak nitelendirilen kavramların sporda yerinin olmadığı, sporun sadece güçlü, hızlı yani mükemmel erkekler tarafından yapılabileceğini söylemektedir.

"Adam gibi adam" ifadesi, erkek egemen toplum yapısının erkeklik ve adamlık kavramlarına yüklediği pozitif anlamları, spor alanında başarı elde etmiş kişilere aktararak aslında erkekliğin, başarının ön koşulu olduğunu söylemektedir. Kültür içerisinde kadınlığı temsil eden özelliklerin ev ve diğer özel alanda kalan yapılarla özdeşleştirilmesi, erkekliğin kadınlığa göre daha üstün olduğu düşüncesini savunmaktadır. Spor basının da içinde bulunduğu kültürden beslendiği ve bu kültür içerisinde yaşayan okurlara seslendiği, kullandığı haber dilinden kolayca anlaşılmaktadır.

Türk spor basını, sporun akla ve sağlam bir mantaliteye dayanan tarafını görmezden gelerek, başarıyı güç ile ölçen ataerkilliğin spor anlayışını benimsemektedir. Sporcuları ve takımları, güç ile ilişkilendirilmiş nesnelere ve yapılara benzeten spor basının cinsiyetçi söylemi, daha önceden eril anlamlar yüklenmiş sözcükleri de haber diline ekleyerek ataerkilliğin getirdiği genel söylemi spor haberleriyle de pekiştirmekte ve yaygınlaştırmaktadır.

\section{b) Saldirganlık}

Aşağıda yer alan haberler incelendiğinde, Türk spor basınının metaforlara ve benzetmelere dayanan haber dilinin, saldırganlık öğeleri içeren söylemlerine tanık olunmaktadır. Haberlerini, çekişme ve gerginliğin üst düzeyde olduğu futbol oyunu çerçevesine oturtturan gazeteler, söylemleri aracılığıyla sporun bir ölüm kalım savaşı içerisinde gerçekleştiğini göstermektedir.

"Yıldırım'dan UEFA'ya Savaş İlanı" (Fotomaç, 2013) "Daha Hırslı Daha İddalı" (Fanatik, 2013) "Sneijder Hirsız Kovaladı" (Fanatik, 2013) "Kartal Artık Adebayor ile "Cenk” Edecek” (Fotomaç, 2013) "Bolu Taarruzu” (Fotomaç, 2013) "Savaşmaya Geldim” (Fanatik, 2013) "Savaşan Kartal” (Fotomaç, 2013) "Horoz Kesmek İsteyenler” (Fanatik, 2013) "Canıyla, Kanıyla, Alın Teriyle Şampiyonluğa Koşuyor” (Fotomaç, 2014) "Terle, Kanla, Gururla” (Fotomaç, 2014) "Galatasaray’n Askerleriyiz" (Fanatik, 2014) "Gerçek Bir Asker: Selçuk" (Fotomaç, 2014) "Devlerin Taht Savaşı” (Fanatik, 2014) "Fırtınadan Yerli Taarruzu” (Fanatik, 2014) "Yürek Savaşçıları" (Fotomaç, 2014) "Barça’la Aslanım” (Fanatik, 2014) "Bize Savaşçı Lazım” (Fanatik, 2014) "Hami’nin Bombacıları" (Fotomaç, 2014) “Aslanın Yeni Avı Ralf” (Fotomaç, 2015) “Orta Saha Köpek Gibi Isıracak” (Fanatik, 2015) “Cardozo Bomba Gibi Geliyor” (Fanatik, 2015) "Kimseden Korkmam” (Fotomaç, 2015) "Rakiplerin Güçlü Olması Beni Asla Korkutmaz" (Fotomaç, 2015) "Özbek Bombaladı" (Fanatik, 2015) "İmparator Emir Verdi: Vurun Kellesini” (Fanatik, 2015) "Pazzini Bombası” (Fotomaç, 2015) "Başkan Esti Gürledi” (Fanatik, 2015) 
"Savaşmak", "taarruz etmek", "cenk etmek", "kesmek", "parçalamak", "bombalamak", "avlamak", "1sırmak", "esip gürlemek", "korkusuz olmak" gibi şiddet ve saldırganlık ifadelerinin geçtiği haberlerden anlaşılacağı üzere, haber dili yoğun bir şekilde savaş metaforları içermektedir. Hegemonik erkekliğin 'savaşçı' erkeklik olarak tanımladığı, korkusuz olmayı, zorluklardan kaçınmamayı, ölümü bile göze alabilecek inanç ve kararlılıkta olmayı dayatan kriterleri, erkekler için spor alanını savaş meydanlarına dönüştürmektedir. Diğer erkeklerin gerisinde kalmanın, erkeklikleri için olumsuz düşünceler yaratacağı inancı, erkeklerin spor alanlarında gösterdikleri saldırganlık boyutundaki performanslarının kaynağını oluşturmaktadır. Yaratılan bu savaşı andıran spor ortamı, spor basınının kullandığı saldırganlık öğeleri içeren söylemini meşrulaştırmaktadır.

"Daha hırslı daha iddialı", "terle kanla", "canıla kanıyla" "askerleriyiz" gibi benzetmelere başvuran ifadelerin yer aldığı haber söylemleri, erkek sporcular için bir hedef göstermektedir. $\mathrm{O}$ hedef, erkeklerin askerlik dönemlerinde yaşadıkları, zorlayıcı fakat altından başarıyla kalktıkları dönemleri işaret etmektedir. Ancak askeri bir disiplinle, katıldıkları spor müsabakalarından başarıyla ayrılabilecekleri düşüncesini besleyen spor basınının bu militarist söylemi, erkekler için en önemli erkeklik deneyimi olan askerlik dönemlerine göndermelerde bulunmaktadır. En sert koşullara, askerlik dönemlerinde dayanabilen erkeklerin, sporun bu zorlayıcı şartlarına da kolaylıkla dayanabileceklerinin mesajı verilmektedir. Militarizmin ve hegemonik erkekliğin birbirini besleyen ilişkisi, spor basınında da kendini göstermekte ve egemen erkek söylemini yaygınlaştırmaktadır.

Şiddet ve saldırganlığın söylemsel zemin içerisine dahil edildiği, gazetelerin erkek egemen söylemi, okuyucuları ile bir bütünlük oluşturmaktadır. Toplumsal yapının beklentilerine uygun olarak çizilen erkeklik kalıpları, spor alanında faaliyet gösteren sporculara oturtulmakta ve oradan da okurlara sunulmaktadır. Birbiriyle içe içe geçmiş cinsiyetçi, şiddet ve saldırganlık içeren ifadeler toplumdaki genel söylemle bu şekilde ilişkilendirildiğinden "göze batmamakta"; böylece bu söylem, spor basınının tekrarlayıcı kullanımları neticesinde normalleştirilmektedir.

\section{c) Kadına Verilen Değer}

Aşağıdaki haberler incelendiğinde, habere konu olan erkek sporcuların kadınlarla ilişkileri ve kadınlık hakkındaki düşünceleri, erkek olmalarının sağladığı rahatlığın verdiği bir güven ile ilişkilendirilerek sunulmuştur.

"Arda Turan’ın Çeşme Keyfi” (Fanatik, 2013)

"Futbol Kadınlardan Güzel” (Fanatik, 2013)

"Selçuk Stres Atıyor" (Fanatik, 2013)

Toplumsal düzende erkekliğe atfedilen evi geçindirme, aileyi koruma, düzeni sağlama vb. gibi roller, erkeklerin bu işleri yapmalarındaki zorluklara değinerek, kadınlar üzerindeki tahakkümlerini meşrulaştıran bir sebep olarak gösterilmektedir. Çalışan- 
larının çoğunun erkek olduğu Türk spor basının sektörel yapısı, kadınlığa bu eril çerçeveden bakmakta dolayısıyla erkekliği kadınlığın üzerinde görmektedir.

Haber dilinde kullanılan "stres atmak", "keyif yapmak" gibi rahatlatıcı davranışlar, haber görsellerinde görüldügü üzere, kadınlar üzerinden yapılmakta; sonuçta, bu sporcuların yaptıkları spor faaliyetlerinin yorgunluğunu, kadınlar ile attığının mesajı verilmektedir. Habere sportif faaliyetleri ile değil de erkek sporcuların stresini attığı bir nesne olarak konumlandırılan kadınlık, bu eril söylem tarafından alçaltılmaktadır.

"Futbol kadınlardan güzel” ifadesinin geçtiği haber arka planda, erkek olarak yaratılmanın kadınlıktan üstün olduğu düşüncesini aktarmaktadır. Erkekliğin ispatlanma alanı olarak düşünülen, fiziksel güce dayanan spor faaliyetleri, kadınların elde edemediği bir değer olarak görülerek, erkekliğin vazgeçilmezleri arasında sayılmaktadır. Egemen erkek dünyasında var olabilme savaşının bir parçası olan spordaki başarı, haber söyleminin aktarımıyla, erkekler nezdinde kadınlardan daha fazla değer taşıdığını göstermektedir.

\section{Erilleştirilen Kadınlar}

Aşağıdaki haberler incelendiğinde, erkeklerle özdeşleştirilmiş toplumsal cinsiyet kimlik özelliklerinin, kadın sporculara aktarıldığı görülmektedir. Gazeteler, kadın sporcuların elde ettiği başarıları konu alan haberlerinde, şiddeti ve saldırganlığı çağrıştıran ifadeler ve takma adlar kullanmıştır.

"Şimşek Gibi Çaktı" (Fotomaç, 2013) "Rakibini Devirip Bir Kez Daha Yarı Finalist Olur” (Fanatik, 2013) "Karatede Dövdük” (Fotomaç, 2013) "Avrupanın Aslanı” (Fotomaç, 2014) "Dişi Melo, Işıl Alben” (Fanatik, 2014) "Aslan Kalpli Kızlar” (Fanatik, 2014) "Kaptan Gemisini Kurtardı" (Fanatik, 2014) "Melo'nun Askerleri” (Fotomaç, 2014) "Serena Ablası Venus'e Acımadı" (Fanatik, 2015)

"Çakmak", “devirmek”, “dövmek”, “acımamak” gibi şiddet anlamlarına sahip kelimeler, kadın sporcuların spordaki başarılarını anlatmak için kullanılmıştır. Böylece, erkekler dünyası olarak adlandırılan spor alanında, kadınların var olabilmelerinin ancak eril özelliklere sahip olunarak başarılabilineceğinin altı çizilmektedir. Eril söylemin kadınlarla ilgili haberlerde etkin olarak kullanılması, kadınların spor alanlarında geleneksel rolleriyle temsil edildiğinin göstergesidir. Kendilerine özgü olmayan niteliklerin haberde, başarılarıyla ilişkilendirilmesi, bunun bir örneğidir.

"Aslan”, "kaptan”, “asker” gibi lakapların kadın sporcular için kullanılması, ataerkil toplum düzeninde, erkeğe yüklenmiş anlamların, kadın sporculara aktarıldığının bir diğer göstergesidir. Toplumsal alanda yönetici pozisyonunda bulunan erkekliğin, övülme sıfat ve isimlerinden olan bu kelimeler, kadınlar için kullanıldığında metaforik anlatım erkekliğe gönderme yapmaktadır. Aslan olan, kaptan olan, asker olan hep erkektir. "Dişi aslan" haberinden anlaşılacağı üzere, haber dilindeki metaforik dil, bir erkek sporcuyu aslan, kadın sporcuyu da o aslanın dişisi olarak nitelendirmektedir. 
Haber dilindeki bu metaforik anlatımın temelinde yatan erkek egemen söylem, kadın sporcuların başarılarını önemsizleştirmekte ve haber dilinin cinsiyetçi yapısını güçlendirmektedir. Öyle ki, kadın sporcuların erkekliği çağrıştıran anlatım biçimlerini ve kelimelerini, kendi takımları ve arkadaşları için övgü sıfatı olarak kullanmaları, haber dilinin toplumsal yapı ile uyumluluğunu ve dile yerleşen cinsiyetçi söylemin varlığını ispatlamaktadır.

\section{4. Önemsizleştirilen Kadın Başarısı}

Erkek spor takımlarının ve erkek sporcuların kazandığı başarıları "destan”, "tarih yazmak", "göğüs kabartmak" gibi yücelten anlamları içeren sözcüklerle tasvir eden gazetelerin, spor organizasyonlarındaki kadın başarılarının ardından nötr bir dil kullandığını görmekteyiz. Aşağıdaki haberler incelendiğinde, erkeklerle kıyaslanan kadınların elde ettikleri başarılar küçümsenerek, önemsizleştirilmektedir.

"Altın Yağmuru” (Fotomaç, 2013) "Minderin Tozunu Attık” (Fanatik, 2013) "Haydi Sultanlar” (Fotomaç, 2013) "Çağla’dan Tarihi Altın Madalya” (Fotomaç, 2013) "Fenerbahçe Ceza Alırsa Kutlamalara Kadın ve Çocuklarla Birlikte Başlayabilir” (Fanatik, 2014) "Kadın Takımımız Gibi Oynayın” (Fotomaç, 2014) “Kızlarımız İmkansızın Başarılabileceğini Bize Gösterdi” (Fotomaç, 2014) “Fener İsyanda” (Fotomaç, 2014) "Yaptıkları Atkı Şovlarla adeta Erkekleri Aratmayan Kadınlar..." (Fanatik, 2014) "Diğer Maçları Hiç Aratmayacak Tezahüratları İle...” (Fotomaç, 2014)

Fotomaç gazetesinin aynı sayfasında yer alan iki ayrı haberde, jimnastik dalında Türk Milli Takımı adına altın madalya kazanan erkek sporcular "tarih yazdılar" ifadesi ile haberleştirilirken, güreş dalında aynı başarıyı gösteren kadın sporcular "altın yağmuru" başlığının altında habere konu edilmiştir. İki haber arasındaki söylem farkı açıkça ortadadır. Zor koşullar altında, üstün bir çaba karşılığında elde edilmiş bir başarı olduğunun altı çizilen, erkek sporcuların haberinin karşısında kadın sporcuların haberi, çok fazla emek sarf etmeden ve yorulmadan elde edilen bir başarıyı anlatır gibi haberleştirilmiştir. Kadın sporcuların yaptığı işin sadece 'gökten yağan altın madalyaları tutmak' olduğunun izlenimi verilmiştir. Fanatik gazetesinde de “tarih yazmak" ile tabir edilen erkek sporcuların başarısı karşısında kadın sporcuların başarısı "minderin tozunu attık" başlı̆̆ının altında önemsizleştirilmektedir. Kazanılan önemli başarı “toz atmak” ifadesinin verdiği 'sıradan' anlamı ile önemsizleştirilmektedir.

"Haydi sultanlar" haber başlığında, kararlılığı ve inancı temsil etmeyen "haydi” kelimesi ile haber dili duygusuzlaştırılmıştır. Erkek sporcuların müsabakaları öncesindeki haberlerinde de saldırganlık ve şiddet anlamları içeren kelimelere başvuran gazeteler, "Haydi" kelimesiyle, voleybol dalında şampiyonluk maçına çıkacak olan kadın voleybol takımına karşı bir tür güvensizliği ifade etmektedir. "İmkansızı başarmak” ifadesinin geçtiği haberden anlaşılacağı üzere, kadın sporcuların elde ettiği başarıları 'mucize' olarak nitelendiren spor basınının bu haber dili, sporda kadın başarılarının önemsizleştirildiğinin göstergesidir. 
Futbol kulüplerinin statlarında kötü tezahürat vb. gibi kurallara uymayan davranışların sergilenmesi halinde, kulüplere Türkiye Futbol Federasyonu tarafından, erkek seyircilerin stada alınmaması cezası verilmektedir. Cezalı bulundukları futbol müsabakalarını kadın ve çocukların giriş yapabildiği statlarda oynayan takımlar, erkek seyircilerin yüksek sesli tezahüratlarından yoksun bırakılmış olurlar. Dezavantaj olarak adlandırılan bu durumun, spor basınına yansıması ise kadın seyircilerin desteğinin önemsizleştirilmesi şeklinde olmaktadır. "Erkek seyircileri aratmayan" ifadesinin kadınları erkeklerle karşılaştıran anlamı, kadınların desteğinin 'beklenmedik' olarak nitelendirildiğinin bir göstergesidir. Kadın sporcuların spordaki başarısına da bu çerçeveden yaklaşan spor basını, kadınları spor müsabakalarında olduğu gibi seyirci konumlarında da önemsizleştirmektedir.

"Kadın takımımız gibi oynayın" cümlesiyle, erkek futbol takımına seslenen Galatasaray futbol kulübü antrenörünün bu ifadesini "ilginç sözlerle motive etmek" cümlesiyle yorumlayan haber, spor basınında alışık olunmadık bir söylemle karşılaşıldığını işaret etmektedir. Kadın sporcuların, erkek sporculara örnek olarak gösterilmesi, egemen erkek söylem içerisinde pek de rastlanacak bir durum değildir. Buradaki diğer bir ayrıntı ise, kadın sporcuların yine eril özelliklerle tasvir edilmesidir. "Erkek gibi oynamak" metaforu ile ilişkilendirilen kadın takımının kazandığı başarı, erkekliğin özelliklerinin gösterilmesiyle elde edildiğini öne çıkaran bir söyleme dönüşmektedir.

Erkek beden gücü ve dayanıklılığa dayanan spor kültürü, kadın sporcuların başarılarına alışkın değildir. Zor şartlar ve uzun bir mücadelenin ardından kazanılan başarılar spor basını tarafından çeşitli uygulamalarla önemsizleştirilmektedir. Önemli başarıların ardından yapılan haberlerin sayfa düzeni içerindeki yeri, haber başlığında ve metninde başarıyı eril özelliklere bağlayan metaforik dil, içerisinde duyguyu ve inancı barındırmayan kelimelerin kullanımı, spor basınının kadın başarılarını önemsizleştirdiğinin göstergelerindendir.

\section{Sonuç}

Fiziksel güce dayanan bir spor anlayışını benimseten toplumsal cinsiyetin ideolojik kurumları, kadınları spor alanında önemsizleştirmektedir. Bu bağlamda toplumsal yapıyı yansıtan, kadın-erkek arasındaki cinsiyete dayalı ayrımcılığın en fazla yapıldığı toplumsal alanların başında gelen spor alanı, çalışmanın araştırma bölümünde incelenmiştir. Medyanın egemen erkek söylemi en fazla yaydığı mecralardan biri olan yazılı basına, sporla ilgili konuları haberleştiren basın türü olması sebebiyle de spor basınına odaklanılmıştır. Türk spor basında en çok tiraja ulaşan gazetelerden; Fotomaç ve Fanatik'de yer alan haberlerin incelendiği çalışmada, cinsiyet ayrımcıllğına dair önemli bulgulara ulaşılmıştır. Spor basının genel bir görüntüsünü sunması açısından yapılan içerik analizi sonucunda, incelenen gazetelerde yer alan haberlerin ezici bir üstünlükle erkeklerle ilgili olduğu gözlenmiştir. Söylemsel çalışmanın zeminini hazırlayacağı düşüncesiyle aktarılan içeriğe dair verilerin ardından, çalışmanın ana yöntemi olan eleştirel söylem analizi ile belirtilen tarih aralığındaki gazete haberleri incelenmiştir. Günlük hayatta sıklıkla rastladığımız, kadınları bir şekilde 
küçümseyen, değersizleştiren ve erkekleri ise yücelten sözcüklere ve deyimlere, incelenen haberlerde de sıkça rastlanılmıştır. Çeşitli konu başlıkları altında incelenen haberler, erkek egemen söylemin, Türk spor basını tarafından da kullanıldığını ve yaygınlaştırdığını göstermiştir. Gazetelerin neredeyse tamamı erkek sporcuları ve erkek takımlarını kapsayan haberlerden oluşturulmuş, az sayıda yer verilen kadın haberlerinde de kadın sporcular ve kadın takımları, cinsiyet ayrımcllğ̆ı öğelerine maruz bırakılmıştır. Erkek sporcuların elde ettiği başarılarının ardından, erkekliği yücelten sıfatlar, sözcükler ve deyimler kullanan gazeteler, kadın başarısını da kullandığı vurgusuz ifadelerle sıradanlaştırarak önemsizleştirmiştir. Kadın sporcuların kazandığı başarıları, toplumda erkeklikle özdeşleştirilmiş ifadelerle sunan gazeteler, kadınların spor alanında erkeklere özgü fiziksel özellikler sayesinde var olabileceklerinin mesajını vermiştir. Yapılan araştırma sonuçları ve haber incelemeleri göstermiştir ki, toplumun kadın ve erkeğe atfettiği değerler, medya tarafından da pekiştirilmekte ve kitlelere aktarılmaktadır. Kadın ve erkek arasında doğdukları andan itibaren başlayan ayrıştırma, zamansal ve mekânsal anlamda değişikliğe uğramadan devam ettirilmektedir. Toplumsallaşmanın her alanında olduğu gibi spor alanında da kadınlar ikinci plana itilmekte ve önemsizleştirilmektedir. Ataerkilliğin ve erkek egemenliğinin dayattığı değerler kadınları olduğu kadar erkekleri de etkilemekte, ideal erkeklik özelliklerine ulaşmak için üstün çaba gösteren erkekler, bu söylemle birlikte insani özelliklerinden ayrıştırılarak adeta "makineleştirilmektedir”. Aile, sosyal çevre ve medya tarafından ayrıştırılan bireyler, karşı cinsiyle çatışması gerektiği düşüncesine kapılmaktadır. Ayrıştırmadan payına daha az değer düşen kadınlar, erkekler tarafından ayrımcılık unsurlarına maruz bırakılmaktadır. Söylemsel olarak yayılan erkek egemenliğine dikkat çekme, spor alanlarında ayrımcllı̆a uğrayan kadınların, sporun erkek gücüne dayalı yapısı karşısında önemsizleştirildiğini gösterme amacı taşıyan bu çalışmayla, toplumsal cinsiyet eşitsizliklerinin önüne geçme noktasında bir farkındalık yaratma da hedeflenmiştir.

\section{Kaynakça}

Alagözlü, Nuray. "Dil ve Cins: Türkçe Atasözlerinde ve Deyimlerde Kadın Üzerine Eğretilemeler ve Toplum-Bilişsel Yapı". International Journal of Central Asian Studies. 13 (2009): 37-48.

Alankuş, Sevda. “Önsöz: Neden Kadın Odaklı Habercilik?”. Habercinin el kitabı: Kadın Odakl Habercilik. Drl. Sevda Alankuş. İstanbul: IPS, 2007.

Berktay, Fatmagül. Tek Tanrılı Dinler Karşısında Kadın. İstanbul: Metis Yayınları, 2000.

Butler, Judith. Undoing Gender. Newyork: Routledge, 2004.

Büyükkantarcıŏglu, S. Nalan. "Söylem İncelemelerinde Eleștirel Dilbilimsel Boyut: Eleştirel Söylem Çözümlemesi ve Ötesi”. Haberi Eleştirmek. Ed. Ömer Özer. Konya: Litaratürk, 2000.

Connell, R. William. Toplumsal Cinsiyet ve İktidar: Toplum, Kişi ve Cinsel Politika. Çev. Cem Soydemir. İstanbul: Ayrıntı Yayınları, 1998. 
Demez, Gönül. (2011). "Sanal Dünyanın Kişisel Alanı: Bir Sosyal Paylaşım Ağı Olarak Facbook'ta Erkek(lik) Tartışmaları”. Medyada Hegemonik Erkek(lik) ve Temsil. Ed. İlker Erdoğan. İstanbul: Kalkedon Yayınları, 2011: 325-352.

Ersöz, A. Günindi. “Türk Atasözleri ve Deyimlerde Kadına Yönelik Toplumsal Cinsiyet Rolleri”. Gazi Üniversitesi Türkiyat Dergisi. 6 (2010): 167-181.

Fanatik. (2013, Haziran 24). “2013-2014 Sivasspor-Yiğidolar”.

Fanatik. (2013, Haziran 25). "İkisinden Birisi Timsah Olacak”.

Fanatik. (2013, Haziran 25). "Paşa Scarione’yi Bitirdi “.

Fanatik. (2013, Haziran 27). "Gakgoş Sollied'i Bekliyor”.

Fanatik. (2013, Haziran 26). “Genç Kızlar Sırbistan'ı Yendi” .

Fanatik. (2013, Haziran 28). "Yenge Milano’yu Özledi”.

Fanatik. (2013, Haziran 30). "Filede Genç Kızlar Kazandı".

Fanatik. (2013, Haziran 28). "Roket Adam Farfan”.

Fanatik. (2013, Haziran 30). "Ferrari Pilotu Gibiyim".

Fanatik. (2013, Haziran 30). "İşte Adam Gibi Adam Slaven Bilic”.

Fanatik. (2013, Haziran 27). "Daha Hirslı Daha İddalı".

Fanatik. (2013, Haziran 27). "Sneijder Hirsız Kovaladı”.

Fanatik. (2013, Haziran 29). "Savaşmaya Geldim”.

Fanatik. (2013, Haziran 30). "Horoz Kesmek İsteyenler”.

Fanatik. (2013, Haziran 25). "Arda Turan’ın Çeşme Keyfi”.

Fanatik. (2013, Haziran 26). "Futbol Kadınlardan Güzel”.

Fanatik. (2013, Haziran 28). "Selçuk Stres Atıyor”.

Fanatik. (2013, Haziran 27). "Rakibini Devirip Bir Kez Daha Yarı Finalist Olur”.

Fanatik. (2013, Haziran 25). "Minderin Tozunu Attık".

Fanatik. (2014, Nisan 15). "Kaplana Bir Şey Olmaz ".

Fanatik. (2014, Nisan 14). "Avrupa Sultanı Galatasaray".

Fanatik. (2014, Nisan 15). "Altın Kizlar”.

Fanatik. (2014, Nisan 15). "Galatasaray'ın Askerleriyiz".

Fanatik. (2014, Nisan 16). "Devlerin Taht Savaşı".

Fanatik. (2014, Nisan 17). "Firtınadan Yerli Taarruzu”.

Fanatik. (2014, Nisan 20). "Barça'la Aslanım”.

Fanatik. (2014, Nisan 20). "Bize Savaşçı Lazım".

Fanatik. (2014, Nisan 14). "Dişi Melo, Işıl Alben”.

Fanatik. (2014, Nisan 14). "Aslan Kalpli Kizlar”.

Fanatik. (2014, Nisan 18). "Kaptan Gemisini Kurtardı".

Fanatik. (2014, Nisan 16). "Fenerbahçe Ceza Alırsa Kutlamalara Kadın ve Çocuklarla Birlikte Başlayabilir” .

Fanatik. (2014, Nisan 20). "Yaptıkları Atkı Şovlarla adeta Erkekleri Aratmayan Kadinlar...”.

Fanatik. (2015, Temmuz 6). “Panzerler Cenk’in Peşinde “. 
Fanatik. (2015, Temmuz 6). "Aslana Göz Kırptı “.

Fanatik. (2015, Temmuz 7). Kara Kartal.

Fanatik. (2015, Temmuz 7). "12 Dev Adam Oluşuyor”.

Fanatik. (2015, Temmuz 9). "Alemin Kralı Geliyor".

Fanatik. (2015, Temmuz 10). "Fırtına Başladı: 5-0".

Fanatik. (2015, Temmuz 12). "Van Persie Kaya Gibi”.

Fanatik. (2015, Temmuz 12). "Makine Poldi".

Fanatik. (2015, Temmuz 7). "Orta Saha Köpek Gibi Isıracak”.

Fanatik. (2015, Temmuz 8). "Cardozo Bomba Gibi Geliyor”.

Fanatik. (2015, Temmuz 9). "Özbek Bombaladı”.

Fanatik. (2015, Temmuz 10). "İmparator Emir Verdi: Vurun Kellesini”.

Fanatik. (2015, Temmuz 12). "Başkan Esti Gürledi”.

Fanatik. (2015, Temmuz 7). "Serena Ablası Venuse Acımadı".

Fotomaç. (2013, Haziran 24). "Trabzonspor Takıma 'Abi' Transfer Edecek".

Fotomaç. (2013, Haziran 28). "Kral Geliyor".

Fotomaç. (2013, Haziran 24). "Periler, İspanya ile Liderlik Maçına Çıkıyor”.

Fotomaç. (2013, Haziran 28). "Yenge Milano’yu Özledi".

Fotomaç. (2013, Haziran 25). "Firtına Turp Gibi".

Fotomaç. (2013, Haziran 27). "Yıldırım'dan UEFA'ya Savaş İlanı".

Fotomaç. (2013, Haziran 28). "Kartal Artık Adebayor İle Cenk Edecek".

Fotomaç. (2013, Haziran 28). "Bolu Taarruzu”.

Fotomaç. (2013, Haziran 29). "Savaşan Kartal".

Fotomaç. (2013, Haziran 24). "Şimşek Gibi Çaktı".

Fotomaç. (2013, Haziran 29). "Karatede Dövdük".

Fotomaç. (2013, Haziran 25). "Altın Yağmuru”.

Fotomaç. (2013, Haziran 30). "Haydi Sultanlar".

Fotomaç. (2013, Haziran 30). "Çağla'dan Tarihi Altın Madalya”.

Fotomaç. (2014, Haziran 17). "Abdurrahim Baba “.

Fotomaç. (2014, Haziran 17). "En Centilmen Gençlerbirliği”.

Fotomaç. (2014, Haziran 17). "Melekler Eczacıbaşı Önünde".

Fotomaç. (2014, Nisan 14). "Canıyla, Kanıyla, Alın Teriyle Şampiyonluğa Koşuyor" .

Fotomaç. (2014, Nisan 15). "Terle, Kanla, Gururla”.

Fotomaç. (2014, Nisan 15). "Gerçek Bir Asker: Selçuk".

Fotomaç. (2014, Nisan 17). "Yürek Savaş̧̧ları".

Fotomaç. (2014, Nisan 20). "Hami’nin Bombacıları".

Fotomaç. (2014, Nisan 14). "Avrupanın Aslanı”.

Fotomaç. (2014, Nisan 20). "Melo’nun Askerleri”.

Fotomaç. (2014, Nisan 16). "Kadın Takımımız Gibi Oynayın".

Fotomaç. (2014, Nisan 16). "Kızlarımız İmkansızın Başarılabileceğini Bize Gösterdi”. 
Fotomaç. (2014, Nisan 18). "Fener İsyanda”.

Fotomaç. (2014, Nisan 20). “Diğer Maçları Hiç Aratmayacak Tezahüratları İle...”.

Fotomaç. (2015, Temmuz 9). “Çaykur Rize’nin Yeni Şövalyesi”.

Fotomaç. (2015, Temmuz 11). "Pitbull Melo İnter'e”.

Fotomaç. (2015, Temmuz 6). "Boğazın Yeni Boğası Loic Remy”.

Fotomaç. (2015, Temmuz 9). "Güçlü Bal-Kes”.

Fotomaç. (2015, Temmuz 6). "Aslanın Yeni Avı Ralf”.

Fotomaç. (2015, Temmuz 8). "Kimseden Korkmam".

Fotomaç. (2015, Temmuz 9). "Rakiplerin Güçlü Olması Beni Asla Korkutmaz”.

Fotomaç. (2015, Temmuz 11). "Pazzini Bombası".

Green, Jamison. Becoming A Visible Man. Nashville: Vanderbilt University Press, 2004.

Güngör, Nazife. İletişim, Kuramlar ve Yaklaşımlar. Ankara: Siyasal Kitapevi, 2013.

Hacısoftaoğlu, İlknur ve Canan Koca. "Spor Medyasında Hegemonik Erkekliğin (Yeniden) Üretimi: 'Delikanlı Gibi Yaşayın, Delikanlı Gibi Oynayın”'. Medyada Hegemonik Erkek(lik) ve Temsil. Ed. İlker Erdoğan. İstanbul: Kalkedon Yayınları, 2011: 69-95.

Johnson, Joy, Lorraine Greaves ve Robin Repta. Better Science With Sex and Gender: A Primer For Health Research. Canada: Women's Health Research Network, 2007.

Kaya, A. Yalçın. “Spor Basınında Dil Kullanımı”. Selçuk Üniversitesi İletişim Fakültesi Dergisi. 2 (2002).

Kaypakoğlu, Serdar. Toplumsal Cinsiyet ve İletişim. İstanbul: Naos Yayınları, 2003.

Kimmel, Michael. The Gendered Society, 2. bs. Newyork: Oxford Üniversity Press, 2011.

Maral, Erol. “İktidar, Erkeklik ve Teknoloji”. Toplum ve Bilim Dergisi. 101 (2004): 127-143.

Meral, P. Seden. "Erkek Hegemonyasının (Yeniden) Üretimi: Dergi Reklamlarında Hegemonik Erkekliğin Temsili”. Medyada Hegemonik Erkek(lik) ve Temsil. Ed. İlker Erdoğan. İstanbul: Kalkedon Yayınları, 2011: 297-323.

Nagoshi, Julie, Craig T. Nagoshi ve Stephan/ie Brzuzy. Gender and Sexual Identity. New York: Springer, 2014.

Oakley, Ann. Sex, Gender and Society. London: Temple Smith, 1972.

Sancar, Serpil. Erkeklik: İmkansız İktidar, Ailede, Piyasada, ve Sokakta Erkekler. İstanbul: Metis Yayınları, 2013.

Smith, R. (1997). “İmgeler ve Eşitlik: Kadınlar ve Ulusal Basın”. Medya, Kültür, Siyaset. Dzl. Süleyman İrvan. Ankara: Ark, 1997: 338-355

Timisi, Nilüfer. Medyada Cinsiyetçilik. Ankara: KSSGM Yayınları,1997.

Van Dijk, Teun A. Text and Context. London: Longman, 1997.

Wilchins, R. A. (2002). Queerer Bodies. J. Nestle, C. Howell, \& R. A. Wilchins içinde, Gender Queer: Voices From Beyond The Sexual Binary. Los Angeles: Alyson.

Worell, Judith. Encyclopedia of Women and Gender. California: Academic Press. 2002 . 


\title{
Gender Discrimination in Turkish Sport Press: A Case Study on Fotomaç and Fanatik Newspapers
}

\author{
MEHMET BÜYÜKAFŞAR
}

\begin{abstract}
The system of social values attributes masculinity an exclusive position. The man considers deserving this privileged position because of handling hard works in society. Starting in the family, gender knowledge is learned in social relations. Media, as an instrument of delivering this gender knowledge, plays an important role in socialization process. The separation that determines the femininity or masculinity in accordance with social genders, are implemented in every field of society by social institutions. Paternal social system is the main reason causing the gender-based discrimination. In paternal societies, the woman exists with her traditional roles. In contrast to the women whose duties are raising children and cleaning the house, the man is symbolized with strength, and durability and assigned with vital duties. As in the most fields of the society, the women are inferior to the men. The sport that is symbolized with strength, competition, ambition and conflict takes the women as a second class because of their lack of physical strength. Therefore, the inequality between the man and the woman is the main point in this study. Also, male dominance, which is spread via news of sport media, is another important point on which this study focuses. For the research, Turkish sport press was chosen. Fotomaç and Fanatik are the two leading newspapers in Turkish sport press. So, The sport news in Fotomaç and Fanatik published in 2013, 2014 and 2015 will be examined just for a whole week time period in order to find out gender discrimination.
\end{abstract}

Keywords: Gender, Sexism, Sports, Sporting Press, Discrimination. 